\title{
PENGARUH PEMBERIAN PROBIOTIK Bacillus subtilis DAN Saccharomyces cerevisiae PADA PRODUKSI LAYER UMUR 24 MINGGU
}

\author{
Saputro N.A ${ }^{1^{*}}$., Lisnanti E.F+2., Rudiono $D^{3}$. \\ ${ }^{1}$ Mahasiswa Studi Peternakan, Fakultas Pertanian, Universitas Islam Kadiri Kediri \\ ${ }^{3}$ Dosen Studi Peternakan, Fakultas Pertanian, Universitas Islam Kadiri Kediri \\ *Corresponding E-mail : nanangas61@gmail.com
}

\begin{abstract}
ABSTRAK
700 ekor Isa Brown digunakan untuk menentukan efek dari probiotik Bacillus subtilis dan Saccharomyces cerevisiae yang 'siap dicampur dalam bentuk probiotik pakan' untuk menghasilkan kinerja pada layer usia 24 minggu. Evaluasi dilakukan selama 4 minggu di kandang Bapak Kholil, yang terletak di Kecamatan Kademangan Desa Dawuhan, Kabupaten Blitar. Perlakuan pakan dibagi menjadi dua kelompok, yaitu: PO (45\% jagung $+13,5 \%$ merek beras

$+7 \%$ tepung tulang daging $+23 \%$ tepung kedelai $+1,5 \%$ premix $+1 \%$ tepung batu) dan $\mathrm{P} 1$ ( $45 \%$ jagung $+13,5 \%$ merek beras $+7 \%$ tepung tulang daging $+23 \%$ tepung kedelai $+1,5 \%$ premix $+1 \%$ tepung batu $+0,1 \%$ probiotik); untuk analisis menggunakan uji t. Parameter dimasukkan: Konsumsi Pakan (g / ekor / hari); FCR; berat telur (g); Produksi Hen Day (\%); Massa Telur (g); dan Penghasilan dari Biaya Pakan (Rp / ekor). Hasil penelitian menunjukkan bahwa tidak ada pengaruh yang signifikan $(P>0,05)$ pada konsumsi pakan $(103,52$ vs $103,66 \mathrm{~g} /$ ayam $)$, berat telur $(56,94 \mathrm{vs} 57,57 \mathrm{~g} /$ telur $)$, namun, ada pengaruh yang signifikan $(P<0,05)$ pada ayam produksi hari $(36,45 \mathrm{vs} 47,42 \%)$, massa telur $(20,78$ vs $2,29 \mathrm{~g})$, rasio konversi pakan $(6,28$ vs 4,40$)$, pendapatan atas biaya pakan masing-masing (121,96 vs -8 , Rp. 72 / ayam). Kesimpulan penelitian ini adalah penambahan bakteri Bacillus subtilis dan Saccharomyces cerevisiae ke dalam pakan sendiri dapat mempengaruhi konsumsi pakan, produksi hari ayam, tingkat konversi pakan dan pendapatan dari biaya pakan untuk ayam petelur pada 24 minggu usia, tetapi tidak berpengaruh pada berat telur.
\end{abstract}

Kata Kunci : Pakan komplit, probiotik, ayam petelur, performa produksi.

\section{THE INFLUENCE OF Bacillus subtilis PROBIOTICS AND Saccharomyces cerevisiae OF THE PRODUCTIONS LAYER CHICKEN AGE 24 WEEKS}

\begin{abstract}
700 heads of Isa Brown layer were used to determine effect of Bacillus subtilis and Saccharomyces cerevisiae bacteria using in "ready to mixed in feed probiotic form" to laying performance on 24 weeks of age. Evaluation were done during 4 weeks of laying period on Mr. Kholil Farm, which is located at Dawuhan Village Kademangan Sub District, Blitar Municipal. The feed treatments were divided into two groups, which are: PO $(45 \%$ corn $+13,5 \%$ rice brand $+7 \%$ meat bone meal $+23 \%$ soybean meal $+1,5 \%$ premix $+1 \%$ stone flour) and P1 $(45 \%$ corn $+13,5 \%$ rice brand $+7 \%$ meat bone meal $+23 \%$ soybean meal $+1,5 \%$ premix $+1 \%$ stone flour $+0,1$ probiotics); there for analysis using is $t$ test. The parameter were included: Feed Comsumption (g/head/day); FCR; egg weight (g); Hen Day Production (\%); Egg Mass (g); and Income Over Feed Cost. The results show that there is no significant effect ( $P>0.05$ ) on feed consumption (103.52 vs $103.66 \mathrm{~g} / \mathrm{chicken}$ ), egg weight (56.94 vs $57.57 \mathrm{~g} / \mathrm{egg})$, however, there is significant effect $(P<0.05)$ on hen day production (36.45 vs 47.42\%), egg mass (20.78 vs $2.29 \mathrm{~g}$ ), feed convertion ratio (6.28 vs 4.40), income over feed cost (121.96 vs $-8, \mathrm{Rp} .72$ /chicken) respectively. The conclution of this study is the addition of Bacillus subtilis and Saccharomyces cerevisiae bacteria into self-mixing feeding is able to influence the feed consumption, the hen day production, the feed convertion rate and the income over feed cost to layer chicken at 24 weeks of age, but it has no effect on the egg weight.
\end{abstract}

Keywords: Complate feed, probiotic, layer, performance productions. 


\section{PENDAHULUAN}

Ayam petelur mempunyai potensi yang cukup besar untuk dikembangkan sebagai usaha peternakan karena memiliki kemampuan yang menguntungkan yaitu mempunyai telur dengan nilai gizi tinggi. Telur merupakan salah satu sumber protein hewani bagi masyarakat Indonesia. Telur ayam ras mampu memenuhi $65 \%$ kebutuhan telur nasional, sisanya dipasok dari ayam kampung, itik dan puyuh.

Kabupaten Blitar memiliki komoditi peternakan terbesar berupa ayam ras petelur, tahun 2010 sebagai potensi unggulan, produksi telur Kabupaten Blitar mampu memenuhi 70\% kebutuhan telur Jawa Timur dan 30\% memenuhi kebutuhan Nasional. Tahun 2018 jumlah populasi ayam ras petelur Kabupaten Blitar mencapai 15.365 .000 ekor dengan jumlah produksi sebanyak 155.802 ton telur. Sentra produksi telur berada di Kecamatan Srengat, Ponggok, dan Kademangan (Data Pemkab Blitar, 2018).

Bahan alternatif yang dapat mengganti fungsi dari antibiotik dalam pakan adalah probiotik Probiotik didefinisikan sebagai bahan pakan tidak tercerna, dan memberikan dampak positif pada inang (host), dengan memacu pertumbuhan/aktifitas bakteri di dalam colon (Choudhari et al., 2008). Pemberian probiotik memiliki beberapa tujuan yaitu untuk menempatkan, memperbaiki atau mengimbangi fungsi mikroba asli yang mendiami saluran pencernaan, mencegah penyakit saluran pencernaan, meningkatkan daya cerna pakan, yang mengarah ke peningkatan penggunaan nutrisi.

Diaz (2008), menyatakan bahwa Penambahan probiotik ke dalam ransum kontrol, akan membantu pencernaan zat- zat makanan di usus halus dan menurunkan populasi bakteri patogen. Pemberian probiotik yang mengandung Bacillus subtilis dan Saccharomyces cerevisiae terhadap layer umur 24 minggu sebagai bahan feed adictive diharapakan mampu meningkatkan produksi telur (hen day production), hen house production, konsumsi pakan, Feed Conversion Ratio (FCR), Income Over Feed Cost (IOFC).

\section{MATERI DAN METODE}

Penelitian ini dilaksanakan di Desa Dawuhan Kecamatan Kademangan Kabupaten Blitar. Waktu dilaksanakan penelitian pada September - Oktober 2019 di kandang Pak Kholil. Materi yang digunakan yaitu: Ayam petelur Strain Isa Brown 700 ekor, probiotik, kandang batteray, dan pakan self mix.

Penelitian ini dilaksanakan dengan metode uji T tidak berpasangan dengan 2 perlakuan dan 14 ulangan. Perlakuan terdiri atas:

P0: Pakan Standart (Jagung, BKK, Bekatul, Tepung batu, MBM, Premix).

P1: Pakan probiotik (Jagung, BKK, Bekatul, Tepung batu, MBM, Premix) + Probiotik.

Setiap perlakuan diulang sebanyak 14 kali dengan satuan percobaan sebanyak 25 ekor. 
Hasil data yang didapatkan kemudian dianalisis menggunakan program Microsoft excel dan dilanjutkan analisis statistik dengan membandingkan $T$ hitung dan $T$ tabel $5 \%(0,05)$.

Variabel yang diamati yaitu : Konsumsi pakan (g/ekor/hari), berat telur (g/butir), Hen Day Production (\%), egg mass (g/ekor), Feed Conversion Ratio (FCR), Income Over Feed Cost (Rp/butir/hari)

\section{HASIL DAN PEMBAHASAN}

Data hasil penelitian secara legkap dapat dilihat pada Tabel 1 berikut.

Tabel 1. Data hasil penelitian

\begin{tabular}{lccc}
\hline \multirow{2}{*}{ Variabel } & \multicolumn{2}{c}{ Perlakuan } \\
\cline { 2 - 4 } & $\begin{array}{c}\text { Pakan Standart } \\
\text { Rata-rata }\end{array}$ & $\begin{array}{c}\text { Pakan Probiotik } \\
\text { Rata-rata }\end{array}$ & Notasi \\
\hline Konsumsi pakan & $103,52 \pm 0,43$ & $103,66 \pm 0,33$ & $\mathrm{~ns}$ \\
(g/ekor/hari) & $56,94 \pm 4,18$ & $57,57 \pm 3,33$ & $\mathrm{~ns}$ \\
Berat telur (g/butir) & $36,45 \pm 15,7$ & $47,42 \pm 16,78$ & $\mathrm{~s}$ \\
Hen day production(\%) & $20,78 \pm 9,04$ & $27,29 \pm 9,81$ & $\mathrm{~s}$ \\
Egg mass & $6,28 \pm 4,22$ & $4,40 \pm 2,02$ & $\mathrm{~s}$ \\
Konversi pakan & $-121,96 \pm 157$ & $-8,72 \pm 165,62$ & $\mathrm{~s}$ \\
IOFC(Rp/ekor) & & &
\end{tabular}

Keterangan : notasi ns (non significant) menunjukkan bahwa diantara perlakuan tidak berpengaruh nyata $(P>0,05)$ dan $s$ (significant) berpengaruh nyata $(P<0,05)$

\section{Konsumsi Pakan}

Konsumsi pakan diketahui dengan menghitung jumlah pakan yang diberikan dikurangi pakan sisa selama 24 jam. Konsumsi pakan digunakan sebagai indikator penting untuk menilai suatu bahan pakan dan berhubungan dengan pemenuhan kebutuhan ternak baik untuk hidup pokok maupun produksi.

Data hasil penelitian yang terdapat pada Tabel 1 menunjukkan bahwa rata- rata konsumsi pakan selama penelitian adalah P0 kontrol (103,52 $\pm 0,43 \mathrm{~g} / \mathrm{ekor} / \mathrm{hari})$ tidak berbeda dari P1 probiotik (103,66 $\pm 0,33 \mathrm{~g} / \mathrm{ekor} / \mathrm{hari})$. Hasil analisis statistik menunjukkan bahwa perlakuan penambahan pakan probiotik Bacillus subtilis dan Saccharhomyces cerevisiae selama penelitian tidak memberikan pengaruh nyata $(P>0,05)$ terhadap konsumsi pakan ayam layer, diduga karena perlakuan penambahan probiotik tidak merubah kandungan zat pakan sehingga masih bisa ditoleransi oleh ayam. Imbangan protein dan energi sangat berpengaruh terhadap jumlah konsumsi pakan karena energi dalam pakan adalah salah satu faktor pembatas konsumsi. Pernyataan ini sesuai pendapat North and Bell (1992) bahwa kandungan energi dalam pakan adalah salah satu faktor pembatas konsumsi. Energi dalam pakan berbanding 
terbalik dengan jumlah konsumsi pakan. Apabila kandungan energi dalam pakan tinggi, akan mengakibatkan konsumsi pakan rendah, dan sebaliknya apabila energi dalam pakan rendah, maka konsumsi akan tinggi.

Konsumsi pakan layer 24 minggu di bawah standart yang telah ditetapkan 105 g/ekor/ hari untuk strain Isa Brown. Jumlah konsumsi pakan dipengaruhi oleh palatabilitas, kecernaan, dan komposisi zat pakan. Hal ini tidak sesuai pernyataan Hariyati (2011) pemberian probiotik yang cukup terhadap ternak dapat mempengaruhi komposisi dan ekosistem mikroflora pencernaan. Kondisi ekosistem mikroflora dalam saluran pencernaan akan mempengaruhi kinerja dan kesehatan ternak.

Pengaruh pemberian probiotik pada ternak terpusat pada perbaikan komposisi dan ekosistem dari pencernaan sehingga pengaruh dari penambahan probiotik dalam pakan lebih ditekankan pada penyerapan nutrisi ataupun proses pencernaan dan bukan pada konsumsi pakan ternak. Hal ini sesuai dengan pendapat (Prawira et al., 2013) konsumsi pakan akan lebih efisien apabila ditambah dengan zat-zat yang dapat meningkatkan efisiensi penggunaan pakan, tetapi tidak menimbulkan residu pada produk yang dihasilkan. Strain ayam, umur ayam, lingkungan dan kualitas nutrisi yang sama menyebabkan kecenderungan bobot badan tiap ekor sama sehingga konsumsi pakan cenderung sama.

\section{Berat Telur}

Berat telur dipengaruhi oleh beberapa faktor, termasuk genetik, tingkat kedewasaan kelamin, beberapa obat dan beberapa zat makanan. Hasil analisis statistik menunjukkan bahwa perlakuan penambahan pakan probiotik Bacillus subtilis dan Saccharhomyces cerevisiae selama penelitian tidak memberikan pengaruh nyata $(P>0,05)$ terhadap berat telur. Pengaruh perlakuan terhadap berat telur dapat dilihat pada tabel 1. Rata-rata menunjukkan berat telur perlakuan penambahan pakan probiotik $\mathrm{P} 1$ (57,57 $\pm 3,33 \mathrm{~g} /$ butir) secara statistika dianggap sama dengan rataan yang pakan standart $\mathrm{PO}(56,94 \pm 4,18 \mathrm{~g} / \mathrm{butir})$.

Berat telur yang tidak menimbulkan pengaruh nyata karena berat telur sangat bergantung pada konsumsi pakan, energi dan protein, karena selain digunakan untuk kebutuhan pokok hidup ayam, kandungan protein dan energi juga dibutuhkan untuk pertumbuhan dan produksi telur. Menurut Harm and Russell (2004) energi berpengaruh signifikan terhadap bobot badan, konsumsi pakan, penyerapan pakan namun tidak berpengaruh pada berat telur. Semakin tinggi energi dalam pakan akan menurunkan berat telur dan konsumsi pakan tetapi tidak meningkatkan bobot badan.

SNI 01-3926-2008 (BSN< 2008) membagi bobot telur menjadi tiga, yaitu kecil $(<50$ g/butir), sedang (50-60 g/butir), besar (>60 g/butir). Berdasarkan data rata- rata berat telur dari pakan standart dan pakan probiotik termasuk dalam kategori 
telur medium. Perbedaan rata-rata berat telur pada perlakuan tersebut tidak terlalu signifikan yaitu 0,63 gram. Hal ini sesuai dengan pendapat Bahlevi et al, (2001) menyatakan bahwa penambahan probiotik dapat memperbaiki produksi telur, konsumsi pakan, tapi tidak pada berat telur.

Ukuran telur merupakan faktor penting yang dapat menentukan penerimaan harga dalam aspek pemasaran. Ukuran telur medium di Indonesia digemari konsumen untuk industri olahan makanan berbahan dasar telur. Telur yang berukuran kecil memliki kualitas isi yang tinggi dibandingkan telur yang besar. Standart ukuran dalam pemasaran telur adalah 56,7 gram per butir. Hal tersebut sesuai dengan penelitian Iriyanti et al.,(2007) bahwa ayam petelur dengan pemberian probiotik menghasilkan bobot telur berkisar antara 40 sampai 60 gram, bobot kuning telur sebesar 9,5 sampai 13 gram.

\section{Hen Day Production}

Hen day production (HDP) merupakan salah satu indikasi untuk mengukur produksi telur dengan cara membandingkan antara produksi telur yang diperoleh dengan jumlah populasi ayam yang hidup saat itu. Hen day production merupakan presentase yang didapatkan dari jumlah telur yang dihasilkan satu hari dibagi dengan total populasi pada hari itu.

Hasil analisis statistik menunjukkan bahwa perlakuan penambahan pakan probiotik Bacillus subtilis dan Saccharhomyces cerevisiae selama penelitian berpengaruh nyata $(P<0,05)$ terhadap hen day production. Data penelitian pada Tabel 1 menunjukkan bahwa rata-rata hen day production adalah P0 kontrol $(36,45 \pm 15,7 \%)$ lebih rendah dari P1 pakan probiotik $(47,42 \pm 16,78 \%)$.

Hen day production menimbulkan pengaruh nyata karena terjadi peningkatan persentase hen day production seiring dengan penambahan probiotik. Konsumsi pakan cenderung sama akan tetapi menghasilkan produksi telur yang berbeda karena perlakuan penambahan probiotik pada pakan. Probiotik yang terkandung di dalam pakan akan meningkatkan penyerapan zat makanan didalam usus halus. Didukung dengan daya cerna protein, energi metabolis, aktivitas enzim yang mendapat bantuan dari adanya probiotik.

$\mathrm{Hal}$ ini sependapat dengan pernyataan Kompiang (2000) bahwa dengan adanya probiotik dapat meningkatkan presentase hen day production. Terlihat dengan penambahan pakan probiotik pada penelitian ini menghasilkan selisih HDP sebesar $10 \%$.

Rata-rata hen day production P1 memang lebih tinggi dari P0 akan tetapi masih jauh dari standart produksi untuk layer umur 24 minggu. Menurut (Sudarmono 2003) persentase hen day production layer umur 24 minggu berkisar $60 \%$, rataan yang sangat jauh dari standart terjadi karena kondisi fisiologis dari layer yang masih dalam tahap pemulihan pasca terserang penyakit, diduga kesalahan manajemen pada awal pemeliharaan sehingga mengakibatkan kegagalan vaksin coryza (snot). 
Penyakit coryza memang tidak menimbulkan mortalitas yang tinggi tetapi morbiditasnya tinggi, selain itu mengakibatkan penurunan produksi sesuai pendapat Blackall (2013) penurunan produksi akibat infeksi coryza dapat mencapai $10-40 \%$ dari produksi standart. Pemberian probiotik mampu berpengaruh pada hen day production sehingga memperbaiki capaian produksi telur harian pada perlakuan penambahan probiotik pada pakan.

Faktor yang mempengaruhi tinggi rendahnya produksi telur adalah genetik seperti jenis ayam, dan umur, kandungan nutrisi dalam ransum, keadaan lingkungan, fisiologis ternak (Anggrayono et al., 2008). Probiotik sebaiknya diberikan pada awal pemeliharaan atau ketika memasuki fase grower 11 minggu, seperti pernyataan Kompiang (2009) bahwa probotik akan lebih efektif jika diberikan pada ternak yang masih muda karena mempengaruhi penyerapan nutrisi dan jumlah ovum yang dihasilkan sehingga kinerja organ reproduksi maksimal dan produksi juga optimal.

\section{Egg Mass}

Egg mass menunjukkan rata-rata berat telur harian sehingga presentase produksi telur harian akan mempengaruhi egg mass. Menurut Amrullah (2003) egg mass atau massa telur merupakan hasil kali antara berat telur dengan HDP. Hasil analisis statistik menunjukkan bahwa perlakuan penambahan pakan probiotik Bacillus subtilis dan Saccharhomyces cerevisiae selama penelitian berpengaruh nyata $(\mathrm{P}<0,05)$ terhadap egg mass. Data penelitian pada Tabel 1 . menunjukkan bahwa rata-rata egg mass adalah P0 kontrol $(20,78 \pm 9,04)$ lebih rendah dari P1 pakan probiotik $(27,29 \pm 9,81)$.

Egg mass menimbulkan pengaruh nyata tetapi nilai kedua perlakuan pakan sangat rendah karena, rataan hen day production di bawah standart. Rendahnya salah satu faktor yaitu berat telur atau hen day production berpengaruh pada nilai egg mass. Hal ini sependapat dengan pernyataan Scannes et al. (2005), massa telur dipengaruhi oleh produksi telur harian dan bobot telur, jika salah satu atau kedua faktor semakin tinggi maka massa telur juga semakin meningkat dan sebaliknya. Penambahan pakan probiotik mengakibatkan peningkatan nilai egg mass karena nilai hen day production $\mathrm{P} 1$ lebih tinggi dari pada $\mathrm{PO}$.

Cath et al. (2012) menambahkan dengan mendefinisikan massa telur sebagai rataan dari bobot telur harian. Persentase produksi telur akan memengaruhi massa telur. Massa telur dipengaruhi oleh produksi telur dan bobot telur, juga dipengaruhi oleh siklus/ irama bertelur (AlNedawi et al., 2008). Nilai egg mass yang rendah tidak terlepas juga akibat dari penyakit coryza yang mempengaruhi capaian hen day production, sesuai beberapa peryataan yang terdapat diatas bila salah satu faktor rendah (hen day production atau berat telur) maka akan berpengaruh pada hasil egg mass.

\section{Konversi Pakan}


Konversi pakan merupakan perbandingan antara konsumsi pakan dengan produksi yang dihasilkan sehingga dengan nilai konversi pakan yang tinggi maka semakin tidak efisien dalam penggunaan pakan. Nilai konversi pakan merupakan salah satu indikator yang dapat memberikan gambaran tingkat efisiensi penggunaan pakan.

Hasil analisis statistik menunjukkan bahwa perlakuan penambahan pakan probiotik Bacillus subtilis dan Saccharhomyces cerevisiae selama penelitian berpengaruh nyata $(P<0,05)$ terhadap konversi pakan. Data penelitian pada Tabel 1. menunjukkan bahwa rata-rata nilai konversi pakan adalah P0 kontrol $(6,28 \pm 4,22)$ lebih tinggi dari P1 pakan probiotik $(4,40 \pm 2,02)$.

Konversi menimbulkan pengaruh nyata tetapi nilainya sangat tinggi dari standart, tingginya nilai konversi pakan diakibatkan oleh hen day production yang rendah. Menurut Mussawarr et al., (2004) Konversi pakan ayam layer umumnya sebesar 2,33 $\pm 0,04$.

Rata-rata konversi pakan yang tinggi terjadi karena kondisi fisiologis ayam masih dalam tahap pemulihan setelah terkena penyakit coryza, tingkat kesehatan ternak mempengaruhi capaian produktivitas, rendahnya produktivitas tentu tidak menguntungngkan bagi peternak. Hal ini sesuai dengan pendapat Saleh et al., (2005) menyatakan bahwa konversi pakan dipengaruhi oleh kadar protein dan energi, metabolis ransum, umur, bangsa ayam, tersedianya zat pakan dalam ransum, suhu, dan kesehatan ayam.

Konsumsi pakan masih terlihat normal akan tetapi hen day production sangat jauh di bawah standart yang ditetapkan. Infeksi penyakit coryza dapat menyerang semua umur ayam, pada penelitian ini menyerang ayam umur 24 minggu dimana umur yang mendekati fase puncak produksi karena sangat merugikan. Penerapan manajemen pemeliharaan yang baik dan kedisiplinan terhadap jadwal vaksin yang telah disusun setidaknya dapat mengurangi resiko dan ketidakpastian serangan penyakit.

Nilai konversi pakan diperoleh dari rasio pakan yang dikonsumsi dalam jangka waktu tertentu dibandingkan dengan bobot telur yang dihasilkan dalam waktu tertentu, perlakuan penambahan probiotik menghasilkan nilai konversi pakan lebih rendah dibandingkan dengan perlakuan kontrol.

Perlakuan penambahan probiotik dalam pakan dapat meningkatkan efisiensi penyerapan nutrisi sehingga berpengaruh pada nilai konversi pakan. Malik (2013) menjelaskan bahwa penambahan probiotik dalam ransum dapat meningkatkan kecernaan dan penyerapan zat-zat nutrisi pada pakan sehingga menghasilkan konversi pakan yang lebih baik. Rusdiyansah (2014) menambahkan bahwa pemberian probiotik dapat memperbaiki pertumbuhan dan angka konversi pakan (FCR). 


\section{KESIMPULAN DAN SARAN Kesimpulan}

Hasil penelitian menunjukkan bahwa perlakuan berpengaruh nyata $(P<0,05)$ pada parameter: hen day production (36,45 vs 47,42\%); egg mass (20,78 vs $27,29 \mathrm{~g})$; feed convertion ratio (6,28 vs 4,40); income over feed cost (-121,96 vs -8,72Rp/ekor). Sedangkan pada parameter: konsumsi pakan (103,52 vs 03,66 g/ekor) dan berat telur (56,94 vs 57,57g/butir) tidak berpengaruh nyata $(P>0,05)$.

\section{Saran}

Berdasarkan hasil penelitian disarankan dalam melakukan penelitian menggunakan ayam dalam kondisi yang normal atau sehat. Pengkondisian ayam dilakukan beberapa hari menjelang penelitian dilaksanakan untuk menghindari resiko yang tidak diinginkan, sehingga pada pelaksanaan akan diketahui hasil mana yang lebih baik diantara perlakuan yang diberikan.

\section{DAFTAR PUSTAKA}

Al-Nedawi, A. M., F. R. Al-Samari and K. A. Al Soudi. 2008. Effect of Pause Size and its Number on Egg Mass for a Stock of White Leghorn in Iraq. Int. J. Poult. Sci. 7 (3): 240-242.

Amrullah, I. K. 2003. Nutrisi Ayam Petelur.Seri Beternak Mandiri. Lembaga Satu Gunung Budi. Bogor.

Anggrayono, H. I., W. Tritiarti. 2008. Energi Metabolis dan Kecernaan Protein Akibat Perbedaan Porsi Pemberian Ransum pada Ayam Petelur. Fakultas Peternakan Universitas Diponegoro, Semarang.

Bahlevi, T., U.S. Ucan., B. Coskun, V. kurtoglu and S. Cetingul. 2001. Effect of dietary probiotic on performance and humoral immune response. British poultry. Science.

Blackall, P.J. 2013. Poultry Disease 6th edition Saunders Elsevier. Philadelphia.

Cath, A.U.,M. Bozkhurt, K. Kucukyilmaz,. Herken, M. Cinar dan E. Bintas. 2012. Performance and egg quality or aged laying hens feed diet supplemented with meat and bone meal or oyster shell meal. South African journal of Animal Science.

Choudhari.et al., 2008. Pengaruh Protein Ransum dan Periode indukan terhadap Bobot badan Akhir, Bobot Karkas, Bobot Non Karkas pada ayam Broiler. Universitas Diponegoro, Semarang.

Diaz, D. 2008. Safety and efficacy of ecobiol as feed additive for chickens for fattening. The EFSA Journal $773: 2-13$.

Harms, R. H., and G. B. Russell. 2004. Performance Of Commrcial Laying Hens When Feed Diets Whith Various Sources Of Energy. J. Appl. Poultry Res. 9:179-184.

Haryati. T. 2011. Probiotik dan Prebiotik sebagai Pakan Imbuhan nonruminansia. J. wartazoa. 21(3):125-132.

Iriyanti, N., M. Mufti dan T. widiyastuti. 2007. Manipulasi pakan dengan Imunostimulan Probiotik dan Prebiotik Terhadap Tampilan Sistem Immunolgik berdasarkan profil darah dan

Vol. $2(2): 81-89$ 
mikroba saluran pencernaan Ayam Petelur, laporan Penelitian DIPA Program Pascasarjana Fakultas Peternakan, universitas jenderal Soedirman, Purwokerto.

Kompiang IP. 2000. Pemanfaatan Mikroorganisme sebagai Probiotik untuk Meningkatkan Produksi Ternak Unggas di Indonesia. Jurnal Pengembangan Inovasi Pertanian.

Kompiang IP. 2009. Pemanfaatan mikroorganisme sebagai Probiotik untuk meningkatakan Produksi ternak di Indonesia ${ }^{1)}$. Pengembangan inovasi pertanian. 2(3):177-191.

Malik, A. 2013. Pengaruh penggunaan probiotik pada ransum terhadap produktivitas dan nilai ekonomi ayam petelur periode layer. Universitas Muhammadiyah. Malang.

Mussawar, S., T.M. Durrani, K. Munir, Z. ul-Haq, M.T. Rahman, dan K. Sarbiland. 2004. Statuse of layer farms in Peshawardivision, Pakistan. Livestock research for rural Development.

North, M. O and D. D. Bell. 1992. Commercial Chicken Production Manual $4^{\text {th }}$ Ed. Chapman and Hall, new York.

Pemerintah Kab. Blitar. 2018. Data Potensi Daerah Peternakan. Pemkab Blitar.

Prawira M.Y, Sarwiyono dan Surjowardjoyo P.,2013, Daya Hambat Dekok Daun Kersen (MuntingiaCalabura L.) terhadap Pertumbuhan Bakteri Staphylococcus Aureus Penyebab Penyakit Mastitis pada Sapi Perah. Jurnal Fakultas Peternakan Universitas Brawijaya.

Rusdiansyah, M. 2014. Pemberian Level Energi dan Protein Berbeda terhadap Konsumsi Ransum dan Air serta Konversi Ransum Ayam Buras Fase Layer. Fakultas Peternakan. Universitas Hasanuddin Makasar. Makasar.

Saleh, E., J. Rifai, dan E. Sari. 2005. Pengaruh pemberian tepung enceng gondok (Eichornia grassipes) dan Paku air (Azolla pinnata) fermentasi terhadap performa ayam broiler. Jurnal Agribisnis Peternakan.

Scannes, C.G., Brant and M.A. Ensminger. 2004. Poultry Science. $4^{\text {th }}$ Ed. New Jersey, USA. Pearson/ Prentice Hall.

Sudarmono, A. S. 2003. Pedoman Pemeliharaan Ayam Ras Petelur. Jakarta: Penerbit Kanisius.

Widjastuti, T. dan R. Kartasudjana. 2006. Pengaruh pembatasan ransum dan Implikasinya terhadap performa burung puyuh. Jurnal Indonesian Tropical Animal Agriculture. 